\title{
K PŘEKLADU ČESKÝCH VÝZNAMŮ POVAHY SLOVESNÉHO DĚJE DO ŠPANĚLŠTINY: APLIKACE MYŠLENEK JIŘíHO LEVÉHO
}

\author{
JANA PEŠKOVÁ
}

\begin{abstract}
The aim of this article is to analyze the strategies that translators apply when transmitting some of the meanings of Aktionsart Czech into Spanish. For this, we start from the fact that Czech is a language where many meanings of the Aktionsart can be expressed by a relatively large set of verbal affixes. This option, however, does not always exist in Spanish. Many meanings of this category tend to be expressed in Spanish through other resources. Therefore, the present article will present the results of analysis of translations of some meanings of Aktionsart extracted from the parallel corpus Intercorp and it will be observed that many of Jiří Levýs postulates are of universal application (for example: selection of lexical units, translation as a decision-making process).
\end{abstract}

Key words: Aktionsart, translation, Jiří Levý, contrastive linguistics, parallel corpus

\section{Úvodem}

V tomto textu bychom chtěli poukázat na některé zákonitosti, které lze pozorovat při prrekladu vybraných lexikálních jednotek $\mathrm{v}$ překladech české beletrie do španělštiny. Lexikálními jednotkami, o které nám zde půjde, budou česká slovesa, která jsou determinována některým významem povahy slovesného děje (např.: dozvánět, pomř́t). Překlad významů, které tato slovesa nesou oproti slovesům základovým (zvonit, zemřít), lze mnohdy označit jako poměrně komplikovaný, a to zejména $v$ př́padě jejich převodu do jazyka typologicky odlišného, v němž tyto významy mohou být formalizovány (gramatikalizovány) jinými výrazovými prostředky. Při analýze překladatelských řešení, jež lze pozorovat $\mathrm{v}$ překladových textech se budeme snažit aplikovat zákonitosti, jichž si v souvislosti s volbou lexikálních jednotek při překladu všímal již J. Levý (zejména tendence $\mathrm{k}$ lexikálnímu ochuzování překladových textů, stereotypnost překladatelských řešení). Vycházet přitom budeme $\mathrm{z}$ jazykových dat získaných na základě rešerše $\mathrm{v}$ paralelním korpusu Intercorp. Jsme si pritom vědomi, jak připomíná P. Čermák (2016: 231), že Levého pojetí překladu není primárně založeno na práci s korpusy, ${ }^{1}$ ale spíše na pohledu na pře-

1 „Los puntos de partida de Levý como traductólogo -y también su objetivo - difieren sustancialmente de los de la lingüística del corpus: mientras que Levý pretende describir el proceso de la traducción entero, 
kladatelský proces jako na celek včetně př́slušných kulturních a historických souvislostí. Práci s korpusem proto chápeme jako nástroj $\mathrm{k}$ rychlému získání relativně obsáhlého objemu jazykových dat, na němž je následně možno výše zmíněné zákonitosti překladatelského procesu sledovat. Naším hlavním cílem zde bude v první řadě poukázat na nadčasovost a univerzální aplikovatelnost některých myšlenek Jiř́ho Levého na př́íladu konkrétních jazykových dat. Sekundárním cílem tohoto článku je snaha o zdokumentování možností respondence několika vybraných významů povahy slovesného děje ve španělštině. Vycházet přitom budeme ze skutečnosti, že čeština je jazykem, v němž je možno řadu významů, které do dané kategorie řadíme, vyjadřovat poměrně bohatým repertoárem slovesných afixů. Tuto možnost španělština vždy nemá, řada významů je ve španělštině vyjádřitelná prostředky jiného charakteru. $V$ následujícím odstavci proto krátce přibližíme povahu slovesného děje z pohledu, jak ji v tomto článku chápeme.

\section{Několik slov k povaze slovesného děje}

Úvodem považujeme za nezbytné připomenout několik obecně známých informací o tom, co přesně rozumíme pod pojmem povaha slovesného děje. Toto upřesnění je nezbytné zejména $\mathrm{z}$ toho důvodu, že mezi tradicemi české jazykovědy a jazykovědy španělské existují rozdílné pohledy na to, jak povahu slovesného děje (Aktionsart) definovat a chápat. ${ }^{2}$ Naše pojetí vychází $z$ tradice české, se španělskými př́stupy se ovšem vyrovnává a snaží se je reflektovat. $Z$ toho důvodu v následujícím odstavci naše chápání této kategorie souhrnně představíme.

Povahu slovesného děje definujeme jako kategorii vyjadřující různé typy modifikací základního významu př́slušného slovesa týkající se fáze, kvality nebo kvantity slovesného děje, které jsou implikované dostupnými prostředky v daném jazyce. ${ }^{3}$ Tímto se naše pojetí zásadně liší od koncepcí španělských, které povahu slovesného děje chápou jako jeden dílčí subtyp aspektuálnosti coby univerzální (tematické) kategorie a vymezují ji jako lexikálně sémantickou kategorii, jejíž významy vychází z inherentní (vnitřní) sémantiky jednotlivých slovesných predikátů. V souladu s tím tak, velice zjednodušeně řečeno, klasifikují slovesa do zhruba čtyř skupin podle toho, zda inherentně vyjadřují děje atelické (amar, escribir) nebo telické (escribir una carta, disparar). Naše pojetí naopak vychází

tomando en cuenta aspectos culturales, históricos, etc., los corpus paralelos quieren almacenar y ofrecer grandes cantidades de datos y proveerlos de instrumentos de búsqueda siempre mejores."

2 Je obecně známou skutečností, že termín povaha slovesného děje (modo de acción verbal, manera de acción verbal, carácter de acción verbal, Aktionsart) se ve španělské lingvistice prosazoval poměrně dlouho. V dřívějších studiích (např. J. Roca Pons, E. Alarcos Llorach, dřivější akademické gramatiky Španělské královské akademie) byl často ne úplně jasně odlišován od termínu aspecto de la acción verbal, který bývá uživán ve smyslu opozice jednoduchého času minulého (hablé) a imperfekta (hablaba). K jistému posunu dochází v 90. letech 20. století, kdy se termín povaha slovesného děje začíná užívat v souvislosti s jevy spojenými s aspektuálností v nejširším slova smyslu, jimž se věnují někteří španělští lingvisté - zejména E. De Miguelová, L. García Fernández. I přesto, a to i po vydání nejnovější akademické gramatiky španělského jazyka Nueva Gramática de la Lengua Española (RAE-ASALE: 2009), je tento termín užíván v jiném významu, nežli tomu je ve studiích bohemistických. Jako významy tzv. lexikálního aspektu (aspecto léxico) neboli Aktionsartu jsou označovány významy, které jsou inherentně obsaženy ve významech jednotlivých sloves.

3 Z českých romanistů na povahu slovesného děje podobně jako my ve svých pracích nahliželi např́klad S. Hamplová (1994), B. Zavadil (1995) nebo J. Šabršula (1962). 
Z vlastností českého slovesa, jehož morfologická specifika složitým způsobem odráží výše zmíněné modifikace základového slovesného významu. To se projevuje například tak, že řada derivačních předpon, jež jsou primárně exponentem dokonavosti ( $p s a l$ - napsal), nepozměňuje význam slovesa pouze gramaticky (vidově), ale i z hlediska povahy slovesného děje. Podle F. Štíchy (2013: 241) je v češtině možno uvažovat o zhruba 19 slovesných prefixech a 6 sufixech, které mohou význam základového slovesa v češtině pozměňovat i lexikálně (např. dopsat, prodebatovat, odpracovat atd.). Tyto lexikální modifikace bývají různého typu, obecně lze tvrdit, že základové sloveso je v češtině modifikovatelné $\mathrm{z}$ hlediska fáze slovesného děje (zejména počátek - např.: rozplakat se; a konec slovesného děje - např.: doplakat), kvantity - např.: naplakat se; nebo kvality slovesného děje - např.: vyplakat se (více např. N. Nübler, J. Petr). Vzhledem k tomu, že španělština pro všechny významy povahy slovesného děje, které mohou být vyjádřeny českými slovesy, nedisponuje srovnatelně rozsáhlým repertoárem výrazových prostředků, je z překladatelského hlediska zajímavé možnosti (a limity) respondence těchto lexikálních jednotek sledovat.

\section{Styčné body kontrastivního studia povahy slovesného děje a myšlenek J. Levého}

V úvodu jsme zmínili, že při našem výzkumu budeme primárně vycházet z příkladů nalezených v překladech české beletrie do španělštiny. Kontrastivní analýza založená na práci s daty excerpovanými z paralelních korpusů by podle našeho názoru neměla směřovat toliko $k$ výčtu a porovnání jednotlivých překladatelských řešení. Naším cílem zde nebude kvalitativně (a možná i subjektivně) hodnotit (ne)vhodnost či (ne)správnost jednotlivých překladatelských řešení užitých pro převod zvolených sloves, implikujících nějaký z výše uvedených významů povahy slovesného děje. Práci s překladovými texty chápeme spíše jako prostředek, jež nám může poodhalit zákonitosti fungování jazykových systémů dvou typologicky odlišných jazyků. Jak říká J. Levý (1971: 147) při hodnocení překladu je třeba vycházet $\mathrm{z}$ předpokladu, že překlad je chápán jako součást komunikačního procesu, ve kterém je třeba: „[...] zkoumat činitele působící na třech stupních překladatelovy práce, tj. při dekódování, interpretování a novém kódování díla, a tak vytvořit teoretickou základnu pro školení překladatelů a pro rozeznání jejich specifických schopností." Snažíme-li tento Levého pohled aplikovat na možnosti respondence českých významů povahy slovesného děje ve španělštině, narážíme na obtíže minimálně ve dvou fázích překladatelského procesu, které jsou Levým zmiňovány, a to a) při dekódování a interpretování prríslušných sémantických konotací některých významů povahy slovesného děje u českého slovesa, b) při novém kódování těchto konotací v cílovém jazyce. Bližším vysvětlením těchto myšlenek se budeme nyní intenzivně věnovat níže s použitím př́ikladů $\mathrm{z}$ korpusu Intercorp. 


\section{Možnosti a meze respondence významů povahy slovesného děje: výběr lexikálních jednotek}

Pro přesné dekódování a interpretaci významu příslušné lexikální jednotky a následné nové kódování těchto konotací v cílovém jazyce je naprosto nezbytné přesně porozumět významu, jehož je daný lexikální segment nositelem. V př́ípadě povahy slovesného děje je možno vystopovat lexikální jednotky (česká slovesa s významem PSD), u nichž tyto fáze problematické spíše nejsou, a ty, u nichž lze při překladu předpokládat určité obtíže. Oběma skupinami se budeme nyní blíže zabývat.

\section{a) Významy povahy slovesného dèje, které jsou „neproblematické“}

Obecně lze říci, že rozhodovací proces při výběru překladatelského řešení je výrazným způsobem regulován faktem, zda v cílovém jazyce (španělština) existují pro danou kategorii (povaha slovesného děje) gramatikalizované prostředky. V př́ípadě že ano, lze předpokládat, že překladatel bude ve veliké míře vybírat respondenty z množiny právě těchto gramatických prostředků. To je př́ípad zejména významů fázových, konkrétně významů spojených s implikováním počáteční a koncové fáze slovesného děje, pro které španělština disponuje relativně početným množstvím opisných slovesných vazeb a které lze označit za systémové respondenty těchto významů [1-2]. Vedle těchto útvarů prémorfologické povahy (termín J. Šabršuly) je možno fázové významy (zejména začátek a konec slovesného děje) v cílovém jazyce nově kódovat i užitím prostředku jiného, např. užitím vhodného adverbia či opisu, jak ukazují jiné příklady [3-4]. Vzhledem k tomu, že dekódování těchto dvou sémantických konotací, jimiž je determinováno př́íslušné lexikálně determinované sloveso, pro zkušeného překladatele není obtížné, ve většině případů lze říci, že tento typ významů PSD je v překladových textech kódován poměrně přesně. Jako př́klad zde uvádíme překladatelská řešení pro finitivní význam povahy slovesného děje, jehož velmi častým nositelem jsou v češtině dějová slovesa derivovaná prostřednictvím předpony do-.

[1]

Když Klára dopověděla nesouvisle a s malým darem srozumitelnosti tuto př́ihodu, řekl jsem:

Cuando Klara terminó de relatar este incidente, en forma entrecortada y con escasas dotes para exponerlo de un modo comprensible, dije:

(Kundera, Milan [1991] Směšné lásky, Brno: Atlantis;

Kundera, Milan [2000] El libro de los amores ridículos, přeložil Fernando de Valenzuela, Barcelona: Grijalbo Mondadori S. A.)

[2]

Samozřejmě proto, abyste nám dopověděl, co jste předtím jen nakousl.

Por supuesto, para que acabara de explicarnos lo que antes sólo había mencionado.

(Urban, Miloš [2001] Sedmikostelí: gotický román z Prahy, Praha: Argo;

Urban, Miloš [2005] Las siete iglesias, přeložil Kepa Uharte Mendicoa, Madrid: Ediciones B)

[3]

On rychle žádal, abych větu dopověděla. 
Él rápidamente me pidió que le dijese la frase hasta el final.

(Hrabal, Bohumil [1994] Morytáty a legendy, Praha: Pražská imaginace;

Hrabal, Bohumil [2000] Leyendas y romances de ciego, přeložily Núria Mirabet, Luisa Rancaño, Barcelona: Destino)

[4]

Ale abych ti to dopověděl, tak ten Jarunka, co spouštěl šraňky, taky napsal Akademii zprávu [...].

Pero para acabar mi historia: pues aquel fulano, Jarunka, el que bajaba y subía las barreras de las vías de tren, mandó un informe a la Academia diciendo que [...].

(Hrabal, Bohumil [2007] Městečko, kde se zastavil čas, Praha: Mladá fronta;

Hrabal, Bohumil [1995] La pequeña ciudad donde el tiempo se detuvo, přeložila Monika Zgustová, Barcelona: Ediciones Destino)

I přesto, že respondentní prostředky v cílovém jazyce existují a volba vhodné lexikální jednotky proto nemusí narážet na větší obtíže, lze narazit na případy, kdy překladatelé z paradigmatu př̀ekladatelských řešení volí to, které daný význam povahy slovesného děje explicitně nesignalizuje. V př́kladu [5] je jako respondent zvoleno základové sloveso ve tvaru jednoduchého času minulého (cenó), jež by mohlo být stejně považováno za respondent slovesa neimplikujícího konec slovesného děje (navečeřel se, najedl se).

[5]

Večer otec dojedl večeři a odjel do práce, přestože jsem měl narozeniny.

Por la noche, mi padre cenó y se fue al trabajo, aunque era mi cumpleaños.

(Urban, Miloš [2001] Sedmikostelí: gotický román z Prahy, Praha: Argo;

Urban, Miloš [2005] Las siete iglesias, přeložil Kepa Uharte Mendicoa, Madrid: Ediciones B)

V př́ikladu [6] zase vidíme, že významový rozdíl mezi slovesy vypít a dopít je (patrně) vyhodnocen jako sekundární a že daná lexikální modifikace nejspíše nehraje pro význam daného výpovědního celku roli natolik zásadní, aby bylo nutno ji nějak více explicitovat. Význam slovesa „vypit“ interpretujeme jako význam vyjadřující dosažení určité hranice v rámci daného slovesného děje - zde např. „vypít ještě [celou] jednu sklenku“, oproti finitivnímu významu slovesa „dopit“, u kterého je fokalizován spíše konec daného slovesného děje. $\mathrm{V}$ překladu vidíme, že je akcentován pouze význam finitivnosti.

[6]

Tatínek se vrátil a zase se napil, řeznice ležela v židli, vlasy jí odstávaly od ramenou, byla čímsi zasažena, vlasy ležely na zemi, jako by tekly z opěradla. Tak tatínek vypil ještě jednu sklenku, a když ji dopil, řeznice jej pohladila po hřbetu ruky a řekla mu neuvěřitelně něžně: „Tak ne.“

Mi padre volvió para beber un poco más, la carnicera estaba reclinada en la silla, el pelo le caía desde la cabeza hasta el suelo, como una cascada que surgiera de la silla. Cuando mi padre terminó su copa, ella le acarició la mano y le dijo con mucha ternura: "No, así no". (Hrabal, Bohumil [2007] Městečko, kde se zastavil čas, Praha: Mladá fronta;

Hrabal, Bohumil [1995] La pequeña ciudad donde el tiempo se detuvo, přeložila Monika Zgustová, Barcelona: Ediciones Destino) 
S těmito „posuny“ se setkáváme i ve směru opačném, tedy při překládání fázových významů povahy slovesného děje ze španělštiny do češtiny. V následujícím příkladu tak vidíme, že v cílovém jazyce (češtině) překladatel z množiny potenciálních respondentů pro význam počátku slovesného děje (vyjádřený ve španělštině opisnou slovesnou vazbou echarse a reír), volí sloveso, které v češtině tímto významem determinováno není. $\mathrm{V}$ prrípadě slovesa vysmát se někomu si zároveň můžeme všimnout toho, jak je povaha slovesného děje $\mathrm{v}$ češtině poměrně silně vázána na okolní kontext, nebot' pokud bychom užili dané sloveso bez přímého předmětu (někomu), došlo by k další modifikaci tohoto slovesa na význam saturativní (vysmát se [dosyta]):

[7]

El jurado se echó a reír y le dijo que iba a retener la escopeta, y que al otro día podría volver en avión a mostrarle los papeles.

Ten se mu vysmál a oznámil mu, že mu zabaví flintu.

(Delibes, Miguel [1980] Diario de un cazador, Barcelona: Ediciones Destino;

Delibes, Miguel [1972] Lovcưv deník, přeložil Josef Forbelský, Praha: Odeon)

Jak jsme uvedli výše, naším cílem zde není hodnotit, zda uvedená řešení považovat za správná a/nebo vhodná, či nikoliv, a ani se je nesnažíme nijak kvantifikovat. Spíše se přikláníme k tomu, že daná řešení (samozřejmě za předpokladu, že hrubě nedezinterpretují myšlenku výchozího textu) lze chápat v souladu s dalším stěžejním konceptem Levého teorie překladu „překlad jako rozhodovací proces“ ve smyslu, že: „Překládání z hlediska pracovní situace překladatele $\mathrm{v}$ každém okamžiku jeho práce (tedy z hlediska pragmatického) je rozhodovací proces, tj. série určitého počtu posloupných situací - tahů jako ve hře -, v nichž se překladatel musí vždy rozhodovat mezi určitým (a zpravidla dosti přesně definovaným) počtem alternativ.“ (J. Levý, 1971: 73) Jak uvádí P. Čermák (2016: 241) při analýze respondentů španělské faktitivní vazby hacer + infinitiv, analýzy založené na práci s korpusovými daty tak mimo jiné mnohdy poodhalují, že překladové respondenty určitých jazykových jednotek mohou být značně heterogenní, významně rozšiřující, „soubor možných alternativ, paradigmat“. V případě některých významů povahy slovesného děje tak docházíme sekundárně k závěru, že $\mathrm{z}$ hlediska překladatelského procesu se některé významy PSD mohou jevit jako akcesorní složka dané výpovědi, přičemž nalezená řešení potvrzují, že mnohdy lze v překladových textech pozorovat hierarchizaci určitých textových segmentů „[...] na prvky důležitější a méně důležité, a také případné překladatelské odchylky na závažnější a méně závažné“ (J. Levý, 1971: 75).

\section{b) Významy povahy slovesného děje, které nejsou „neproblematické“}

V jiných případech bývají sémantické nuance, jimiž se odlišují některé významy povahy slovesného děje od významů základových sloves, na první pohled velice jemné a (de) kódování těchto jemných významů v cílovém jazyce může být složitější. Jako příklad bychom mohli uvést významy sloves zemřit - pomřit - odumřít - odumírat. Možnosti respondence jsou $\mathrm{v}$ těchto případech limitovány jednak tím, jak překladatelé výše uvedené modifikace lexikálního významu vnímají (dekódují) a posléze také tím, jaké systémové prostředky jsou pro vyjádření dané konotace $\mathrm{v}$ cílovém jazyce $\mathrm{k}$ dispozici. Za základové sloveso $\mathrm{v}$ tomto př́ipadě považujeme sloveso zemřit. Význam slovesa pomřít 
označujeme jako význam distributivní PSD, přičemž mezi distributiva zahrnujeme slovesa, která „vyjadřují několikanásobný průběh děje v časové posloupnosti“ (Nübler, 2017). Jejich dalším společným rysem je schopnost implikovat členitost uvnitř jednoho děje, na rozdíl od sloves násobených (iterativních), jež spíše akcentují děje, které se jako celek vícekrát opakují (např. Hamplová, 1994: 115). Sloveso odumř́t se v češtině velice často vyskytuje ve valenci s neživotnými subjekty (odumřely prsty, nohy). Jeho význam lze chápat ve smyslu „odloučení určité části od celku“, nebo i jako modifikaci časovou implikující zakončení slovesného děje (Štícha, 2013: 252), která podle našeho názoru mưže být částečně nazírána i jako děj distributivní (odumřely prsty jeden po druhém). Sloveso odumírat, které je nedokonavým, sekundárním imperfektivem derivovaným od dokonavého odumřít, oproti svému dokonavému protějšku navíc explicitněji vyjadřuje děj nazíraný jako nedokončený, postupně se rozvíjející. Máme-li vzájemně porovnat způsoby, jimiž jsou v cílovém jazyce tyto významy kódovány, zjištujeme, že v řadě případů výše uvedené významové konotace explicitně odlišovány nejsou a jejich častým respondentem je tak „pouhéc základové sloveso morir:

[8]

A jako poslední toho lazaretu jel otevřený kastlák, dva saniteráci tam vysvlékali z lazaretního kabátku mrtvolu, kterou potom hodili na hromadu ztuhlých mrtvol, vojáků, kteří pomřeli cestou $[\ldots]$.

Y el último de aquel hospital era un furgón abierto, dos enfermeros desnudaban allí del hábito hospitalario a un cadáver al que después tiraron a un montón de cadáveres rígidos de soldados que habían muerto durante el viaje [...].

(Hrabal, Bohumil [1994] Ostře sledované vlaky, Praha: Pražská imaginace;

Hrabal, Bohumil [1997] Trenes rigurosamente vigilados, přeložil Fernando de Valenzuela, Barcelona: Ediciones Península)

\section{[9]}

[...] byla ta druhá stránka mého fraku, ten rub všech pinglů a pikolíků a vrchních na celém světě, bílá naškrobená košile a třpytivě bílý kaučukový límec, a zvolna černající nohy, jako při nějaké hrozné nemoci, kdy začnou lidé odumírat od nohou [...].

[...] aquello era el lado opuesto de mi frac, el revés de todos los aprendices, camareros, maîtres de todo el mundo, camisa blanca almidonada y cuello blanco luminoso de celuloide, y los pies, lentamente, ennegreciéndose como por alguna terrible enfermedad de la que las personas empezaran a morir desde los pies [...].

(Hrabal, Bohumil [1993] Obsluhoval jsem anglického krále, Praha: Pražská imaginace; Hrabal, Bohumil [1989] Yo que he servido al rey de Inglaterra, přeložili Jitka Mlejnková, Albert Ortiz, Barcelona: Destino)

[10]

Řekl, že my všichni jsme zapřáhli své mozky do služeb svých úzce specializovaných povolání a snažíme se ze všech sil, aby nám ostatní mozkové závity odumřely.

Dijo que todos hemos puesto nuestros cerebros al servicio de nuestras profesiones altamente especializadas y que nos esforzamos en que muera el resto de nuestras neuronas.

(Jirotka, Zdeněk [1991] Saturnin, Praha: Československý spisovatel;

Jirotka, Zdeněk [2004] Saturnino, př̀ložil Eduardo Fernández Couceiro, Praha: Karolinum) 
K podobným výsledkům docházíme i při analýze možností respondence sloves $s$ jiným významem povahy slovesného děje, např. sloves $s$ významem perdurativnosti4: protancovat [celou noc] oproti tancovat [celou noc]. Častým respondentem perdurativního významu je v nalezených překladech opis prostřednictvím slovesa pasar ve spojení s gerundiem př́slušného významového slovesa:

[11]

Ano, nestydí se to říci, celou noc proplakala.

Sí, no le daba vergüenza decirlo, se había pasado llorando toda la noche.

(Jirotka, Zdeněk [1991] Saturnin, Praha: Československý spisovatel;

Jirotka, Zdeněk [2004] Saturnino, přeložil Eduardo Fernández Couceiro, Praha: Karolinum)

[12]

„Vidíte, vidíte, jste potom samý regma a celý noci prohekáte, “ řekla Rosetka a štítivě špičkou střevíčku odhrnula mokrý hadr a postavila se o schod nad matku.

Lo ve, lo ve, después tiene reuma y se pasa las noches quejándose - dijo Rosetka y con la punta del zapatito, con asco, retiró el cubo mojado y se puso un escalón por encima de su madre.

(Hrabal, Bohumil [1993] Pábitelé, Praha: Pražská imaginace;

Hrabal, Bohumil [1996] Los palabristas, přeložily Eva Kruntorádová, Núria Mirabet, Barcelona: Destino)

Nicméně tato řešení $\mathrm{v}$ překladech často alternují s další poměrně velkou skupinou respondentů, u nichž daný význam podchycen není [13]. Překladatel volí sloveso z hlediska povahy slovesného děje neutrální, nepř́íznakové; rozdíl mezi základovým slovesem a slovesem $s$ významem povahy slovesného děj v překladu patrný není:

[13]

Večer se sešel s Alicí, aby spolu jako vždy probloumali hodinu dvě po ulici, ale Eduard už ve svém náboženském horlitelství nepokračoval.

Por la tarde se encontró con Alice para vagar, como de costumbre, una o dos horas por las calles, pero Eduard no siguió con su fervor religioso.

(Kundera, Milan [1991] Směšné lásky, Brno: Atlantis;

Kundera, Milan [2000] El libro de los amores ridículos, přeložil Fernando de Valenzuela, Barcelona: Grijalbo Mondadori S. A.)

\section{Ochuzování lexika a stereotypnost překladatelských řešení}

Díky současnému rozvoji korpusové lingvistiky je v dnešní době možno jednotlivá překladatelská řešení užitá pro převod určité lexikální jednotky nebo textového segmentu poměrně přesně pozorovat. Je pochopitelně velice těžké generalizovat, jaké důvody

4 Jako perdurativní označujeme slovesa implikující trvání slovesného, které je zpravidla explicitována časovým komplementem v akuzativu: prospat celou noc. Tím se tato slovesa odlišují od sloves typu vyspat se, u nichž je naopak slovesný děj modifikován kvalitativně vyspat se dobře a jež označujeme jako saturativa. 
vedou překladatele k užití té či oné strategie. Výběr lexikální jednotky je, jak ostatně lze vyčíst i u Levého (1998), determinován jak faktory objektivními (kontext), tak faktory subjektivními. K výběru lexikálních jednotek Levý říká, že „ve shodě s psychologií překladatelské práce však mají [překladatelé] sami spíše sklon k zobecňování, neutralizaci a opakováni““ (J. Levý, 1998: 145). „Překladatelská práce svádí ke třem typům stylistického ochuzování slovníku: (i) užitím obecného pojmu místo konkrétního přesného označení, (ii) užitím stylisticky neutrálního slova místo citově zabarveného, (iii) malým využíváním synonym k obměňování výrazu.“ (J. Levý, 1998: 139) Na četné příklady lexikálního ochuzování narážíme i při sledování možností lexikální respondence u českých významů povahy slovesného děje. Zajímavé je, že k tomuto lexikálnímu ochuzování dochází napříč všemi významy povahy slovesného děje, a to jak těmi, jež ve španělštině jakožto cílovém jazyce gramatikalizovány jsou (viz výše například finitivnost), tak těmi, které nejsou (viz výše např́klad distributivnost). Lexikální ochuzování se dále netýkají pouze tendencí zobecňovat některé konkrétní modifikace slovesného děje jednotkami, které tuto modifikaci neimplikují (pomřit $\rightarrow$ morir, protancovat $\rightarrow$ bailar, atd.), ale i občasnou tendencí k užívání stylisticky neutrálních sloves na místo sloves citově zabarvených, které jsou zároveň determinovány i nějakým významem povahy slovesného děje (doprasit něco $\rightarrow$ ensuciar algo, rozeštkávat se $\rightarrow$ ponerse a llorar, prochrápat něco $\rightarrow$ quedarse durmiendo):

[14]

A tak se tedy nenudili, až jednó jeli na dva dny a medvídek se tak nudil o tom svatým Duchu, že rozházel ty veliký kachlový kamna v pokoji a doprasil tak nábytek a peřiny a prádlo v kostnu, že stréc Metud sedl a napsal do Moravské orlice inzerát: [...].

Ya no se aburrían, claro, y una vez se ausentaron dos días por pentecostés y el osito sí que se aburría, y mucho, tanto que destrozó todos los azulejos de la cocina económica y ensució tanto los muebles y los edredones y las sábanas del baúl que el tío Metud se sentó y escribió un anuncio para El Águila de Moravia: [...].

(Hrabal, Bohumil [1976] Postřižiny, Praha: Československý spisovatel;

Hrabal, Bohumil [1976] Personajes en un paisaje de infancia, přeložila Monika Zgustová, Barcelona: Destino)

[15]

Po chvíli se rozeštkává.

$\mathrm{Al}$ cabo de un rato se pone a llorar.

(Kundera, Milan [1997] Valčík na rozloučenou, Brno: Atlantis;

Kundera, Milan [2005] La despedida, přeložil Fernando de Valenzuela, Barcelona: Tusquets Editores)

\section{[16]}

Právě takhle se asi povaloval na gauči ve své vysokoškolské mansardě, když tam před mnoha lety (to byl ještě Eduard klouček) prolenošil a prochrápal den Stalinovy smrti [...].

Seguramente habría estado así, como ahora, tumbado en el sofá, cuando hacía muchos años (Eduard era entonces un crío) se quedó holgazaneando y durmiendo el día de la muerte de Stalin $[\ldots]$.

(Kundera, Milan [1991] Směšné lásky, Brno: Atlantis;

Kundera, Milan [2000] El libro de los amores ridículos, přeložil Fernando de Valenzuela, Barcelona: Grijalbo Mondadori S. A.) 
Tato tendence k zobecňování některých sloves determinovaných významy povahy slovesného děje může být patrná i tehdy, když se k jednomu významu povahy slovesného sekundárně přidruží význam další. K tomu může dojít například změnou vidu, jak jsme již viděli výše u sloves odumř́it - odumírat. Dále také užitím dvou prefixů a současně změnou vidu, jak ukazuje prŕklad slovesa dovyzvánět [17]: prefix do- je nositelem významu konce slovesného děje, prefix $v y$ - je oproti základovému slovesu zvonit nositelem významu intenzity slovesného děje a užitím slovesa ve vidu nedokonavém je navíc děj vyjádřený tímto slovesem nazírán jako průběhový, kurzívní. V překladu je však explicitován pouze důraz na děj nazíraný jako kurzívní, průběhový, a to užitím základového slovesa (tocar - zvonit) ve tvaru imperfekta.

\section{[17] \\ [...] vzala jsem deštníček a rozevřela jej, avšak ono svítilo polední slunce a zvon dovyzváněl poledne, nade mnou se nakláněl pan Pokorný, z ubrousku mu kapala voda a svezlo se pár franclí zelí, [...]. \\ [...] tomé el paraguas y lo abrí, pero el sol de mediodía brillaba y las campanas tocaban las doce, encima de mí se inclinaba el señor Pokorny, de su servilleta chorreaba agua y caían trocitos de col a la vinagreta, [...]. \\ (Hrabal, Bohumil [1976] Postřižiny, Praha: Československý spisovatel; \\ Hrabal, Bohumil [1976] Personajes en un paisaje de infancia, přeložila Monika Zgustová, Barcelona: Destino)}

Podobným případem je i následující prríklad znovu se rozzvracet [18], kde jsou rovněž současně vyjádřeny dva významy PSD, ale dvěma různými prostředky: význam opakovaného děje, jež je zachován i v překladu (opisná slovesná vazba volver a + infinitiv), je vyjádřen prostřednictvím adverbia (znovu) a význam začátku slovesného děje, který v cílovém jazyce vyjádřen není, prefixem roz-. U tohoto segmentu si navíc můžeme všimnout i dalšího př́ikladu neutralizace dvou významů povahy slovesného děje, jež jsou vyjádřeny slovesem zadíval se: počátku slovesného děje spojeného s významem intenzity slovesného děje, jimž v překladu odpovídá sloveso contemplar.

\section{[18]}

A po pískem vysypané stezičce dva zřízenci speditérského podniku nesli na kurtech pískovcovou sochu nějakého bojovníka v kủži a se sekyrkou napřaženou k ráně, a když ti zřízenci vystoupili do schodů, mrskali nožkama a dál nesli na kurtech tu sochu na kterou když se pan Valerián zadíval, znovu se rozzvracel, už neměl co, tak bučel do kbelíku jak na lesní roh.

Y por el camino cubierto de arena dos empleados de una empresa de transportes cargaban a lomos una estatua de arenisca de guerrero en cueros y con un hacha levantada para golpear, y cuando los empleados subieron la escalera movían las piernas con premura y seguían llevando a lomos aquella estatua, y el señor Valerián al contemplarla volvió a vomitar, pero ya no tenía qué, así que sólo mugió dentro del cubo como una trompa.

(Hrabal, Bohumil [1994] Inzerát na di̊m, ve kterém už nechci bydlet, Praha: Pražská imaginace;

Hrabal, Bohumil [1989] Anuncio una casa donde ya no quiero vivir, přeložily Clara Janés, Jana Stancel, Barcelona: Ediciones Península) 
V těchto př́padech je lexikální ochuzování poměrně běžné a již si ho ve svém výzkumu italských sloves všimla S. Hamplová (1994: 91): „italština nemá schopnost tohoto povahově dějového ,vrstvení, a proto překladatelé mohou zachytit jen jednu povahu děje [...]“. Ke stejnému závěru docházíme i u př́kladů španělských.

\section{Závěrem}

$\mathrm{Na}$ výše uvedených př́ikladech převodu některých významů povahy slovesného děje jsme chtěli poukázat na nadčasovost a univerzálnost některých Levého myšlenek. Levý zcela bezesporu dokázal poměrně přesně pojmenovat typologii posunů, $\mathrm{k}$ nimž při překládání určité lexikální jednotky může docházet a jež dnes, díky rozvoji korpusových nástrojů, můžeme pozorovat na velice rozsáhlém vzorku dat. Některé české významy povahy slovesného děje jsou významově velice specifické (rozzvracet se, odumřít). Z překladatelského hlediska lze problémy, které mohou při překládání představovat, částečně přirovnat $\mathrm{k}$ problémům, které se např́klad $\mathrm{v}$ rámci odborných textů řeší v souvislosti s hledáním respondentů pro tzv. bezekvivalentní lexikum. $Z$ toho důvodu jsme se v tomto př́spěvku pokusili na převod těchto lexikálních jednotek nahlédnout optikou toho, co k výběru lexikálních jednotek ř́kal Levý. Zjistili jsme, že zákonitosti, na které Levý poukazoval, lze vystopovat i v prŕpadě převodu českých sloves s významy povahy slovesného děje.

\section{BIBLIOGRAFIE}

Alarcos Llorach, Emilio (1987) Estudios de gramática funcional del español. Madrid: Gredos.

Cuartero Otal, Juan, García Fernández, Luis, Sinner, Carsten (2011) Estudios sobre perífrasis y aspecto, Munchen: Verlag Anja Urbanek.

Čermák, Petr (2016) 'La traducción como proceso de decisiones: su reflejo en los textos paralelos', Mutatis Mutandis 9(2): 224-246.

Dubský, Josef (1956) 'Laspect du verbe et l'action verbale en français et en espagnol', in Sborník prací Filosofické fakulty University J. E. Purkyně, Brno: Filosofická fakulta University J. E. Purkyně.

García Fernández, Luis (1998) El aspecto gramatical en la conjugación. Madrid: Arco/Libros.

García Fernández, Luis (ed.) (2006) Diccionario de perífrasis verbales. Madrid: Gredos.

García Fernández, Luis (2012) Las perífrasis verbales en español, Madrid: Castalia.

Hamplová, Sylva (1968) 'Acerca de la manera de acción y el problema de su expresión mediante las perífrasis verbales en español', Philologica Pragensia 11: 209-231.

Hamplová, Sylva (1994) K problematice vidovosti v italštinè. Praha: Universita Karlova.

Hamplová, Sylva (2001) 'Aspetto verbale v pojetí moderních italských lingvistư, ČMF 82 (2001/2): 85-9.

Levý, Jiří $(1983,1998)$ Umění prekladu, Praha, Ivo Železný.

Levý, Jiří (1971) Bude literární věda exaktní vědou? Praha: Československý spisovatel.

Miguel Aparicio, Elena De (1999) 'El aspecto léxico', in Ignacio Bosque and Violeta Demonte (ed.) Gramática Descriptiva de la Lengua Española, Madrid: Espasa, 2977-3060.

Morimoto, Yuko (1998) El aspecto léxico: delimitación. Madrid: Arco/Libros.

Nübler, Norbert (2017) 'Způsob slovesného děje', in Petr Karlík, Marek Nekula and Jana Pleskalová (eds.), CzechEncy-Nový encyklopedický slovník češtiny: https://www.czechency.org/slovnik/ZP\%C5\%AE SOB\%20SLOVESN\%C3\%89HO\%20D\%C4\%9AJE (access: 18. 1. 2018).

Petr, Jan (ed.) (1986) Mluvnice češtiny II. Praha: Academia. 
RAE-ASALE = Real Academia Española / Asociación de Academias de la Lengua Española (2009) Nueva gramática de la lengua española, Madrid: Espasa Libros.

Real Academia Española (1991) Esbozo de una nueva gramática de la lengua española, Madrid: Espasa Calpe.

Roca Pons, José (1958) Estudios sobre perifrasis verbales del español, Madrid: CSIC (Revista De Filología Española; Anejo LXVII).

Roca Pons, José (1977) 'Sobre los verbos auxiliares en las lenguas románicas', in Actas del XIV Congreso de Lingüística y Filología Románicas III: 313-324.

Šabršula, Jan (1962) Nominálně verbální konstrukce a povaha děje ve francouzštině, Praha: Universita Karlova.

Štícha, František (2013) Akademická gramatika spisovné češtiny, Praha: Academia.

Zavadil, Bohumil (1995) Současný španělský jazyk II. Základní slovní druhy: slovesa, Praha: Univerzita Karlova.

Zima, Jaroslav (1956) ‘Sloveso odzkoušet', Naše řeč 48(2): 124-126.

\section{Zdroj dat}

Rosen, Alexandr and Martin Vavř́n (2016) Korpus InterCorp - čeština, verze 9 z 9. 9. 2016, Praha: Ústav Českého národního korpusu FF UK: http://www.korpus.cz (access: 18. 1. 2018).

\section{RESUMEN}

El objetivo del presente artículo es analizar las estrategias que los traductores aplican a la hora de transmitir algunos de los significados de Aktionsart (modo de acción) checo al español. Para ello, partimos del hecho de que el checo es un idioma donde muchos significados de las Aktionsarten pueden expresarse mediante un conjunto relativamente amplio de afijos verbales. Esta opción, sin embargo, no siempre existe en español. Muchos significados de esta categoría tienden a ser expresados en español por medio de otros recursos. Por lo tanto, en el presente artículo se presentarán los resultados de análisis de traducciones de algunos significados de Aktionsart extraídos del corpus paralelo Intercorp y se observará que muchos de los postulados de Jiř́ Levý son de aplicación universal (entre otros: selección de unidades léxicas y traducción como proceso de decisiones).

PhDr. Jana Pešková, Ph.D.

Ústav romanistiky, Filozofická fakulta Jihočeské univerzity v Českých Budějovicích peskova@ff.jcu.cz 